This is the peer reviewed version of the following article: Olmos Giupponi, Belen (2019) Fostering environmental democracy in Latin America and the Caribbean : an analysis of the Regional Agreement on Environmental Access Rights. Review of European, Comparative \& International Environmental Law, 28(2), pp. 136-151., which has been published in final form at https://doi.org/10.1111/reel.12274 . This article may be used for non-commercial purposes in accordance with Wiley Terms and Conditions for Use of Self-Archived Versions. 


\title{
Fostering environmental democracy in Latin America and the Caribbean: An analysis of the Regional Agreement on Environmental Access Rights
}

\author{
Belén Olmos Giupponi
}

\section{Correspondence}

Email: Belen_Olmos_Giupponi@biari.brown.edu

Principle 10 of the 1992 Rio Declaration laid the groundwork for the implementation of access to environmental information, public participation and access to environmental justice, which constitute the three pillars of environmental democracy. The 2012 United Nations Conference on Sustainable Development marked a turning point in this evolution as Latin American and Caribbean (LAC) countries launched the negotiations for a treaty embodying these environmental rights. This process resulted in the adoption of the Regional Agreement on Environmental Access Rights (RAEAR) in March 2018. This presents a unique opportunity to reflect not only on the RAEAR but, more broadly, on the implementation of environmental rights in LAC. The article first addresses the question of the delayed implementation of environmental democracy rights in LAC. The article then critically analyses the RAEAR provisions and the lessons to be learned from the negotiations. Finally, it underlines outstanding challenges in the implementation.

\section{INTRODUCTION}

Principle 10 of the 1992 Rio Declaration has been pivotal for the implementation of the rights to access to environmental information, public participation in environmental decision making and access to environmental justice (environmental access rights), which constitute the three pillars of environmental democracy. ${ }^{1}$ Relevant international environmental law scholarship has considered the recognition of these rights a quantum leap in the protection of human rights. ${ }^{2}$

Ever since the adoption of the Rio Declaration, the implementation of environmental access rights in Latin America and the Caribbean (LAC) has been on the agenda of governments, international organizations and nongovernmental organizations (NGOs). However, specific proposals for an international legally binding instrument were delayed. The 2012 United Nations (UN) Conference on Sustainable Development (Rio+20) marked a turning point, as nine LAC countries proposed a regional convention embodying environmental access rights. ${ }^{3}$ In their declaration, the signatory countries endorsed the commitment to draft a regional agreement on environmental access rights with the initial aim of concluding the negotiations by December 2017. ${ }^{4}$ The UN Economic Commission for Latin America and the Caribbean (ECLAC) offered the necessary support, acting as technical secretariat.

The roadmap set by the ECLAC for the adoption of this regional agreement foresaw an ambitious agenda, laying the groundwork for the approval of the final text. From the outset,

\footnotetext{
${ }^{1}$ Rio Declaration on Environment and Development in 'Report of the United Nations Conference on Environment and Development' UN Doc A/CONF.151/26 (vol I) (12 August 1992) Principle 10. On compliance with access rights see $<\mathrm{http}: / / \mathrm{www}$.environmentaldemocracyindex.org/>.

2 A Boyle, 'Human Rights and the Environment: Where Next?' (2012) 23 European Journal of International Law 613.

3 'Resolution 686(XXXV), Application of Principle 10 in Latin America and the Caribbean' in Economic Commission for Latin America and the Caribbean (ECLAC) 'Biennial Report (2012-2013)' UN Doc LC/G.2631P (2014).

${ }^{4}$ From 2012 until March 2018, six meetings of the focal points of the signatory countries and fourteen meetings of working groups were held. The negotiations of the regional agreement were opened in November 2014 with the creation of an ad hoc Committee.
} 
stakeholder participation was crucial for drafting a text comprising the main environmental principles and access rights. To illustrate this, the international network of hundreds of civil society groups called The Access Initiative pledged to campaign for the adoption of the text in Chile, Costa Rica, the Dominican Republic, Jamaica, Mexico, Panama, Paraguay, Peru and Uruguay. ${ }^{5}$

Environmental access rights gained momentum as the negotiations for a regional convention in LAC unfolded over four years. Efforts came to fruition with the adoption of the Regional Agreement on Access to Information, Public Participation and Access to Justice in Environmental Matters in Latin America and the Caribbean on 4 March 2018 in Costa Rica (also known as the Escazú Agreement). The conclusion of this Regional Agreement on Environmental Access Rights (RAEAR) is a unique opportunity to reflect on the adopted text as well as on the trajectory of environmental access rights in international environmental law. Section 2 first addresses the delayed implementation of environmental access rights in LAC, examining the progress achieved so far. Section 3 then turns to the RAEAR, including its legal basis and main features. Section 4 analyses how outstanding implementation challenges could be overcome through the RAEAR's compliance mechanism, as well as through lessons learned from the experience of the Aarhus Convention and the Inter-American human rights system (IAHRS). ${ }^{6}$ Section 5 concludes with a discussion of the convergence on environmental access rights, proposing an implementation strategy for the RAEAR.

\section{UNTANGLING THE PROTECTION OF ENVIRONMENTAL ACCESS RIGHTS IN LATIN AMERICA AND THE CARIBBEAN}

The 1972 Stockholm Declaration ushered in a new era in the protection of environmental rights, recognizing the right 'to freedom, equality and adequate conditions of life, in an environment of a quality that permits a life of dignity and well-being'. ${ }^{7}$ Principle 10 operated as the driver for legislative change in international environmental law and national legal systems. Notwithstanding progress made in international environmental law, the reception and full implementation of environmental democracy rights ${ }^{8}$ in some regions, such as LAC, has been hindered due to multiple factors. ${ }^{9}$ The protection of environmental rights in the region is multi-layered, taking place at different levels (national, regional and international). However, significant obstacles to the effective implementation of international environmental law exist. ${ }^{10}$

\subsection{The legal landscape of environmental access rights}

Since the 1990s, a growing number of international environmental treaties have encompassed environmental access rights. ${ }^{11}$ In Europe, the Convention on Access to Information, Public Participation in Decision-making and Access to Justice in Environmental Matters (Aarhus

\footnotetext{
${ }^{5}<\mathrm{http}: / /$ www.accessinitiative.org/>.

${ }^{6}$ P Sands and J Peel, Principles of International Environmental Law (3rd edn, Cambridge University Press 2012) 644.

7 'Declaration of the UN Conference on the Human Environment' UN Doc A/Conf.48/14 (5 June 1972) 11 ILM 1416.

${ }^{8}$ See $n$ 1. See also the work and reports published by the UN Special Representative on Human Rights and the Environment:

$<$ https://www.ohchr.org/en/Issues/environment/SRenvironment/Pages/SRenvironmentIndex.aspx>.

${ }^{9}$ ECLAC, 'Observatory on Principle 10'<http://observatoriop10.cepal.org/es $>$.

${ }^{10} \mathrm{~J}$ May and E Daly, Global Environmental Constitutionalism (Cambridge University Press 2016) 4.

${ }^{11}$ J Viñuales, 'The Rio Declaration on Environment and Development: Preliminary Study' in J Viñuales, (ed.), The Rio Declaration on Environment and Development: A Commentary (Oxford University Press 2015) 1, 32; J Ebbesson, 'Principle 10' in Viñuales, ibid 287.
} 
Convention) enshrined environmental access rights with a specific scope and a regional focus. ${ }^{12}$ Specific multilateral environmental agreements (MEAs) also incorporate some environmental access rights such as public participation: for instance, the Convention of Biological Diversity (CBD), ${ }^{13}$ the UN Framework Convention on Climate Change (UNFCCC) $)^{14}$ and the Minamata Convention, ${ }^{15}$ among others.

Outside international environmental law, the implementation of environmental access rights has been advanced through public interest litigation before regional human rights courts. ${ }^{16}$ Principle 10-related issues have been argued in various manners and with regional differences. In Europe, the European Court of Human Rights (ECtHR) has chiefly relied on this principle to protect the right to a private and family life in line with Article 8 of the European Convention of Human Rights and the freedom of expression as enshrined in Article 10 in relation to access to environmental information. ${ }^{17}$

In addressing the implementation of environmental access rights vis-à-vis human rights norms, environmental law scholars draw the distinction between the former as 'procedural rights' ${ }^{18}$ and the latter as 'substantive rights'. ${ }^{19}$ Although the distinction may be useful to dissect and analyse the panoply of rights from a theoretical standpoint, both types of rights are interrelated in practice.

In LAC, environmental law scholars consider access to environmental information as a fundamental part of the right to an adequate environment enshrined in national constitutions. Severino Ortega, for instance, underlines that the evolution towards the recognition of environmental access rights (particularly access to environmental information) has been hailed by the enactment of progressive national legislation. ${ }^{20}$ In turn, Orellana emphasizes that even though international human rights law and international environmental law constitute two different fields, there are areas of convergence as evidenced by international and regional legal instruments and case law. ${ }^{21}$

Among the theoretical considerations sustaining this new trend is environmental constitutionalism, ${ }^{22}$ involving 'the confluence of constitutional law, international law, human rights, and environmental law'. ${ }^{23}$ Put simply, environmental constitutionalism reflects the outcome of the intersections between international law and domestic law in the protection of

\footnotetext{
12 Convention on Access to Information, Public Participation in Decision-Making and Access to Justice in Environmental Matters (adopted 25 June 1998, entered into force 30 October 2001) 2161 UNTS 447 (Aarhus Convention).

${ }^{13}$ Convention on Biological Diversity (adopted 5 June 1992, entered into force 29 December 1993) 1760 UNTS 79 art 14.

${ }^{14}$ United Nations Framework Convention on Climate Change (adopted 29 May 1992, entered into force 21 March 1994) 1771 UNTS 107.

${ }^{15}$ Minamata Convention on Mercury (adopted 10 October 2013; entered into force 16 August 2017) 55 ILM 582.

${ }^{16}$ C Schall, 'Public Interest Litigation Concerning Environmental Matters before Human Rights' (2008) 20 Journal of Environmental Law 417.

17 See, e.g., Guerra and Others v Italy App No 14967/89 (ECtHR, 19 February 1998) para 60; McGinley and Egan $v$ United Kingdom App No 21825/93 and 23414/94 (ECtHR, 9 July 1998) para 101; Taşkin and others $v$ Turkey App No 46117/99 (ECtHR, 10 November 2004) para 119; and Roche v United Kingdom App No $32555 / 96$ (ECtHR, 19 October 2005) para 162.

${ }^{18}$ May and Daly (n 10) 77.

${ }^{19}$ See J Brunnée, 'Procedure and Substance in International Environmental Law: Confused at a Higher Level?' (2016) 5 ESIL Reflection 1; and B Peters, 'Unpacking the Diversity of Procedural Environmental Rights: The European Convention on Human Rights and the Aarhus Convention' (2018) 30 Journal of Environmental Law 1. ${ }^{20}$ T Severino Ortega, 'El Derecho de Acceso a la Información Ambiental, Hitos y Desafíos' (2011) 7 Derecho Ambiental y Ecología, México 38.

${ }^{21}$ M Orellana, 'Derechos Humanos y Ambiente: Desafíos para el Sistema Interamericano de Derechos Humanos' (2007) 292-293.

${ }^{22}$ LJ Kotzé, ‘Arguing Global Environmental Constitutionalism’ (2012) 1 Transnational Environmental Law 199.

${ }^{23}$ May and Daly (n 10).
} 
environmental rights. This is in line with constitutional and public law theories that emerged in LAC in the 1980s and 1990s, when several constitutions were reformed to include the protection of environmental rights. As Brañes has observed, during this period there was a considerable 'greening' of Latin American constitutions with the inclusion of provisions on environmental protection. ${ }^{24}$

These various theoretical underpinnings seem to come together in the ECLAC's vision which is reflected in the integrationist approach to the different rights taken in the RAEAR. ${ }^{25}$

\subsection{Environmental access rights in Latin America: Legal and judicial progress}

Legal developments in LAC have been the result of both exogenous and endogenous factors. Regarding the first set of factors, the influence of international environmental law through MEAs and the active role of international and regional organizations have contributed to legislative change. In terms of endogenous factors, environmental constitutionalism, activism and mobilization for environmental justice have led to demands for more transparency in environmental decision making. In turn, different trends have been decisive for the recognition of environmental access rights, in particular, the impact of global and regional environmental governance and the emergence of environmental litigation.

The first trend concerns global and regional environmental governance. At the global level, the United Nations Environment Programme (UNEP) has strengthened environmental law compliance through the Guidelines for the Development of National Legislation on Access to Information, Public Participation and Access to Justice in Environmental Matters (Bali Guidelines). ${ }^{26}$ The Organization of American States (OAS) has also played a regional role in the promotion of sustainable development, with the adoption of the 2002 Latin American and Caribbean Strategy for Sustainable Development addressing inequalities in the region. A more supportive regional agenda on sustainable development has raised the protection of access rights, as expressed in various regional instruments. ${ }^{27}$

Regional integration organizations such as the Central American Integration System, the Community of Caribbean States, the Andean Community and the Common Market of the South (Mercosur) have also enacted legal instruments concerning environmental protection, such as the 2001 Mercosur Environmental Agreement ${ }^{28}$ and the several Central-American agreements in environmental matters. ${ }^{29}$ This regional environmental governance has also produced policy documents and strategies to implement MEAs in the respective region. ${ }^{30}$

\footnotetext{
${ }^{24}$ R Brañes, El Acceso a La Justicia Ambiental en América Latina (UNEP Mexico 2000).

${ }^{25}$ See, e.g., ECLAC, 'Access to Information, Participation and Justice in Environmental Matters in Latin America and the Caribbean: Situation, Outlook and Examples of Good Practice' (2013); and ECLAC 'Acceso a la Información, la Participación y la Justicia en Asuntos Ambientales en América Latina y el Caribe: Hacia el Logro de la Agenda 2030 para el Desarrollo Sostenible' UN Doc LC/TS.2017/83 (2018).

${ }^{26}$ UNEP 'Decision SS.XI/5, Guidelines for the Development of National Legislation on Access to Information, Public Participation and Access to Justice in Environmental Matters' UN Doc UNEP/GCSS.XI/11 (3 March 2010) Annex.

${ }^{27}$ For instance: the Inter-American Strategy for the Promotion of Public Participation in Decision Making for Sustainable Development; the 2006 Declaration of Santa Cruz+10; the 2010 Declaration of Santo Domingo for the Sustainable Development of the Americas; the 2012 Principle 10 Declaration; and the 2013 Declaration of Santiago of the Community of Latin American and Caribbean States (CELAC); see MB Olmos Giupponi, Rethinking Free Trade, Economic Integration and Human Rights in the Americas (Bloomsbury 2016).

28 A Correia Lima, 'MERCOSUR and Environmental Law' in M Franca Filho, L Lixinski and MB Olmos Giupponi, The Law of Mercosur (Hart 2010) 225.

${ }^{29}$ See $<$ https://www.sica.int/consulta/entidades.aspx?IdEnt=2\&Indv=2\&IdmStyle=1\&Idm=1 >; and G Aguilar and A Iza, 'Manual de Derecho Ambiental para Centroamerica' (2005).

${ }^{30} \mathrm{~F}$ De Castro, B Hogenboom and M Baud (eds), Subregional Environmental Governance in Latin America (Palgrave 2016).
} 
Networks specializing in environmental compliance, which bring about cooperation focused on capacity building, have also emerged, such as the Central American Commission on Environment and Development (CCAD). ${ }^{31}$

Environmental litigation has also advanced the cause of access rights in LAC. Three different strands of environmental litigation at the national, regional and international levels have harnessed this evolution. At the national level, procedural avenues provided for in various LAC constitutions to protect human rights (amparo, recurso de protección, tutela) have been invoked to safeguard the environment. Further procedural developments led to a class action or an actio popularis to defend the environment, recognized now in public law and case law. In Colombia, citizens can protect the environment through the acción popular; and in Argentina, the Supreme Court ruled in 2009 that class action suits are admitted to protect the environment. Another procedural tool is the organization of public hearings in environmental cases. In the Caribbean, environmental access rights have been upheld in various cases lodged before domestic courts. ${ }^{32}$

At the regional level, litigation in the IAHRS, comprising the Inter-American Commission (IACHR) and the Inter-American Court of Human Rights (IACtHR), has given rise to a significant body of jurisprudence on environmental access rights. ${ }^{33}$ Both human rights bodies have integrated Principle 10 in the safeguard of human rights. To illustrate, the IACHR referred to the right to access to information in Huenteao Beroiza. This case arose from the construction of a dam on indigenous lands in Chile without providing access to the petitioners even though the Indigenous Peoples Act required that the relocation of the indigenous population should only proceed with the consent of those affected. The Commission was confronted with a conflict of rights between investors and indigenous communities that finally resulted in an amicable settlement. ${ }^{34}$ The IACtHR has included Principle 10 in the protection of the right to indigenous property under Article 21 of the American Convention on Human Rights (ACHR). ${ }^{35}$ Specifically, the Court has protected indigenous property rights by referring to Principle 10, upholding the right to free, prior and informed consent (FPIC) of indigenous peoples in Awas Tingni, ${ }^{36}$ Sarayaku, ${ }^{37}$ Saramaka ${ }^{38}$ and Kaliña and Lokono peoples. ${ }^{39}$ The Court further reminded litigants in Kaliña and Lokono of the separate obligation of the State to conduct an environmental and social impact assessment performed by 'independent and technically-qualified entities, under the State's supervision, [who] have made a prior assessment of the social and environmental impact', respecting and ensuring the effective participation of the indigenous people. ${ }^{40}$ The IACtHR has also recently issued an advisory opinion on the relationship between international environmental law and international human

\footnotetext{
$31<$ https://www.sica.int/ccad/>.

${ }^{32}$ ECLAC and Caribbean Court of Justice (CCJ) Academy of Law 'Ensuring Environmental Access Rights in the Caribbean: Analysis of Selected Case Law’ UN Doc LC/TS.2018/31 (2018).

${ }^{33}$ Orellana (n 21).

${ }^{34}$ Inter-American Commission on Human Rights, 'Report No 30/04, Petition 4617/02, Friendly Settlement, Mercedes Julia Huenteao Beroiza et al. v Chile’ (11 March 2004).

${ }^{35}$ Mayagna (Sumo) Awas Tingni Community v Nicaragua, Inter-American Court of Human Rights Series C No 79.

36 ibid.

${ }^{37}$ Matter of Pueblo Indigena de Sarayaku regarding Ecuador (Provisional measures), Inter-American Court of Human Rights (6 July 2004) (only in Spanish); Matter of Pueblo Indigena de Saravaku regarding Ecuador (Provisional measures), Inter-American Court of Human Rights (6 June 2005) (only in Spanish).

${ }^{38}$ Saramaka People v Suriname, Inter-American Court of Human Rights Series C No 172 (28 November 2007) para 93; see L Brunner, 'The Rise of Peoples' Rights in the Americas: The Saramaka People Decision of the InterAmerican Court of Human Rights' (2008) 7 Chinese Journal of International Law 699.

${ }^{39}$ Kaliña and Lokono Peoples v Suriname, Inter-American Court of Human Rights Series C No 309 (25 November 2015) (Kaliña and Lokono).

40 ibid para 214.
} 
rights law upon the request by Colombia. ${ }^{41}$ In the advisory opinion, the Court interpreted the right to life and the right to personal integrity as well as the State's obligations to respect human rights in light of international environmental law, emphasizing the States' obligations in guaranteeing environmental access rights. ${ }^{42}$

Alongside the regional bodies, other subregional judicial and quasi-judicial bodies created in the framework of regional integration processes (such as the Central American Court of Justice, the Andean Court of Justice or Mercosur arbitral tribunals) may offer another forum for the implementation of environmental access rights. However, these courts have rarely addressed environmental concerns. By contrast, the Caribbean Court of Justice (CCJ) could become important in the protection of environmental right, as most Caribbean States have not accepted the jurisdiction of the IACtHR. An example of the CCJ's incipient role in the protection of environmental rights is the case of Mayan communities in Belize, whose lands rights were upheld in a 2015 judgment. ${ }^{43}$ The CCJ submitted that the right to protection of the law, defined as 'a multi-dimensional, broad and pervasive constitutional precept grounded in fundamental notions of justice and the rule of law' ${ }^{44}$ had been breached 'by the failure of the State to secure and ensure the enjoyment of constitutional rights'. ${ }^{45}$

More generally, in recent inter-State disputes brought before the International Court of Justice (ICJ) involving environmental issues, the ICJ upheld fundamental environmental law principles which, interpreted together, further foster the evolution of access rights in the region. In Pulp Mills, the ICJ determined that the prevention principle as an emanation of due diligence constitutes a customary norm in environmental impact assessment (EIA) processes. ${ }^{46}$ In the cases concerning the San Juan River brought by Costa Rica and Nicaragua, in analysing the parties' pleadings the ICJ incidentally mentioned the Convention on Biological Diversity, which provides for public participation in the EIA process. ${ }^{47}$

\subsection{The socio-political context and the implementation of environmental access rights in LAC}

Notwithstanding these legal developments, environmental protection in LAC can still be considered underdeveloped. Specific constraints and obstacles to implementation that stem from institutional and political settings in LAC countries bring further hurdles.

According to the International Network for Environmental Compliance and Enforcement (INECE), the region faces several interrelated challenges. One of the most acute problems in LAC is air pollution due to densely populated urban areas with limited waste treatment facilities, which expose the population to considerable health risks and lead to a lack

\footnotetext{
${ }^{41}$ Environment and Human Rights (State Obligations Regarding the Environment Within the Framework of the Protection and Guarantee of Rights to Life and Personal Integrity - Interpretation and Scope of Articles 4.1 and 5.1, in Relation to Articles 1.1 and 2 of the American Convention on Human Rights), Advisory Opinion OC-23/17, Inter-American Court of Human Rights Series A No 23 (15 November 2017) (Advisory Opinion 23/17); 'Request of Advisory Opinion submitted by the Republic of Colombia before the Inter-American Court of Human Rights' $(14$ March 2016) <http://www.corteidh.or.cr/solicitudoc/solicitud_14_03_16_ing.pdf >

${ }^{42}$ American Convention on Human Rights (adopted 22 November 1969, entered into force 18 July 1978) 21 ILM 58 arts $1(1), 4(1)$ and 5(1).

43 Maya Leaders Alliance $v$ The. Attorney General of Belize [2015] CCJ 15 (AJ) $<$ https://www.elaw.org/system/files/2015-CCJ-15AJ.pdf $>$.

44 ibid para 7.

45 ibid.

${ }^{46}$ Pulp Mills on the River Uruguay (Argentina v Uruguay) (Judgment) [2010] ICJ Rep 14 para 110.

${ }^{47}$ Certain Activities Carried Out by Nicaragua in the Border Area (Costa Rica v Nicaragua) and Construction of a Road in Costa Rica along the San Juan River (Nicaragua v Costa Rica) (Judgment) [2015] ICJ Rep paras 163 and 164. The ICJ nonetheless concluded that the CBD 'does not create an obligation to carry out an [EIA] before undertaking an activity that may have significant adverse effects on biological diversity'; ibid para 164.
} 
of access to safe drinking water. In terms of biodiversity, the region is the reservoir of many endangered species that suffered as a consequence of unrestrained deforestation. Natural resources-driven development results in uncontrolled mining and unsustainable agricultural practices (mainly related to soy farming), which cause enormous discharges of runoff, pesticides and other toxic chemicals, thus polluting water bodies and coastal areas. ${ }^{48}$ While natural resources are abundant in the region, environmental conflicts over access or control of natural resources are recurrent. ${ }^{49}$ Finally, environmental defenders have been constantly at risk in the region, which offers a sad record of human rights violations committed against them. The need to protect environmental defenders was confirmed by the IACtHR, which has emphasized the State's responsibility to protect their human rights. ${ }^{50}$

To address these pressing issues, regional environmental legal frameworks have undergone several changes over the last 30 years, with national environmental legislation adopted in various sectors. Environmental legislation in Central America, South America and the Caribbean is quite recent, with comprehensive environmental laws adopted or reformed between 1981 (Brazil) and 2012 (Dominica). ${ }^{51}$ EIA legislation has also paved the way for a new era in public participation and environmental compliance. Slow-motion progress is observed in certain key areas such as environmental crime.

International environmental law has harnessed legislative change in LAC, particularly in vital areas such as those falling under the CBD regime, empowering indigenous peoples in reaching benefit-sharing agreements. ${ }^{52}$ Yet, the implementation deficit in sectoral environmental legislation is still significant. One possible reason for the slowing down of implementation is the lack of resources. ${ }^{53}$

Even though the basic foundations for environmental protection and access rights are in place, LAC States need to enact further legislation under each of the different pillars and adopt specific implementation strategies to counteract existing shortcomings.

\subsection{The contribution of the RAEAR}

The RAEAR has the potential to have a positive impact on the protection of environmental rights in various ways. What is distinctive about the agreement is the approach to environmental access rights: it reinforces the implementation of environmental access rights through regional human rights law, building on the precedents of the IAHRS. Throughout the text, environmental rights are entrenched with the protection of human rights. Notably, the preamble contains several references to international human rights law, denoting a particular stance on environmental rights, since they are conceived in their substantive and procedural dimension as human rights. ${ }^{54}$ In the ECLAC's words, the RAEAR 'is a ground-breaking legal

\footnotetext{
$48<$ https://www.inece.org/regions/region/1>.

${ }^{49}$ For an overall analysis of compliance with environmental legislation in LAC, see, e.g., ECLAC, Environmental SDG Indicators: Progress and Challenges (2009). For an appraisal of ongoing environmental conflicts, see R Sexton, Environment and Conflict in Latin America (URD 2012).

${ }^{50}$ Kawas Fernández v Honduras, Inter-American Court of Human Rights Series C No 196 (3 April 2009).

${ }^{51}$ ECLAC, 'Acceso a la información, participación y justicia en temas ambientales en América Latina y el Caribe: situación actual, perspectivas y ejemplos de buenas practices’ (ECLAC 2013) 20, 21.

${ }^{52}$ On the implementation of the CBD in Latin America, see CBD, 'The State of Biodiversity in Latin America and the Caribbean' (UNEP 2016) < https://www.cbd.int/gbo/gbo4/outlook-grulac-en.pdf> and ECLAC (n 51).

53 Latin American Environmental Compliance and Enforcement Network (REDLAFICA), 'Bases de la Fiscalización Ambiental (Organismo de Evaluación y Fiscalización Ambiental - OEFA 2016)' $<$ http://www.redlafica.org/publicaciones $>$.

${ }^{54}$ DL Shelton, 'Developing Substantive Environmental Rights' (2010) 1 Journal of Human Rights and the Environment 89.
} 
instrument for environmental protection, but it is also a human rights treaty'. ${ }^{55}$ This has concrete implications, as the agreement can be invoked and applied through the IAHRS. In line with this idea, in the advisory opinion on human rights and the environment the IACtHR looked at human rights through the lens of international environmental law, asserting 'the existence of an undeniable relationship between the protection of the environment and the realization of other human rights'. ${ }^{56}$

The RAEAR alludes to interactions with other international legal instruments and to the achievement of the 2030 Sustainable Development Goals. ${ }^{57}$ The agreement also addresses specific regional interests such as climate change-related aspects and the protection of indigenous peoples. ${ }^{58}$

The long time spent negotiating the agreement may be explained by the fact that the agreement does not admit reservations, hence the need for the States to scrupulously negotiate every single term of the text. ${ }^{59}$ To expedite the process, the agreement will enter into force on the ninetieth day after the date on which the fifth instrument of ratification, acceptance, approval or accession has been deposited. ${ }^{60}$

In sum, this legally binding agreement on environmental access rights could boost the development of national legislation, giving rise to best practices.

\section{UNPACKING ENVIRONMENTAL CORE PRINCIPES AND OBLIGATIONS IN THE RAEAR}

At first sight, the RAEAR seems to embody provisions analogous to those of the Aarhus Convention. However, the text also contains several provisions specific to the LAC region, for instance, on the protection of environmental defenders, indigenous peoples and persons and groups in vulnerable situations, the latter defined as 'those persons or groups that face particular difficulties in fully exercising the access rights recognized in the present Agreement, because of circumstances or conditions identified within each Party's national context and in accordance with its international obligations'. ${ }^{61}$

Core concepts for protecting environmental rights are expressed in the preamble, such as interdependency and essential principles for their effective implementation. Interdependency of environmental access rights is considered key to achieving the promotion and implementation of environmental legislation in an 'integrated and balanced manner'. ${ }^{62}$

The RAEAR provides a list of environmental principles: (i) the principle of equality and non-discrimination; (ii) the principles of transparency and accountability; (iii) the principle of non-regression and progressive realization; (iv) the principle of good faith; (v) the preventive principle; ${ }^{63}$ (vi) the precautionary principle; (vii) the principle of intergenerational equity; (viii) the principle of maximum disclosure; (ix) the principle of permanent sovereignty of States over natural resources; $(\mathrm{x})$ the principle of sovereign equality of States; and (xi) the principle of pro

\footnotetext{
${ }^{55}$ Regional Agreement on Access to Information, Public Participation and Justice in Environmental Matters in Latin America and the Caribbean (adopted 4 March 2018, not yet entered into force) $<$ https://repositorio.cepal.org/bitstream/handle/11362/43583/1/S1800428_en.pdf $>$ (RAEAR) 7.

${ }^{56}$ Advisory Opinion 23/17 (n 41).

${ }^{57}$ UNGA 'Transforming Our World: the 2030 Agenda for Sustainable Development' UN Doc A/RES/70/1 (21 October 2015).

${ }^{58}$ See, e.g., RAEAR (n 55) preamble.

59 ibid art 22.

${ }^{60} \mathrm{ibid}$ art 21. The process of ratification opened on 27 September 2018.

${ }^{61}$ ibid art 2(e).

62 ibid preamble.

${ }^{63}$ This is likely referring to the prevention principle.
} 
persona. ${ }^{64}$ The measures adopted to fulfil the Convention's objectives and the application of its provisions shall be guided, inter alia, by these principles. Along well-established principles in international environmental law, other more innovative principles appear in the agreement. Particularly, the pro persona principle has been extrapolated from regional human rights law, based on the IAHRS pro homine principle, which guides the interpretation of international human rights treaties. Accordingly, treaty provisions must be 'interpreted in favour of the individual, who is the object of international protection as long as such an interpretation does not result in a modification of the system' ${ }^{65}$ Other novel principles are those of transparency, accountability and non-regression and progressive realization. However, whereas transparency and accountability have been widely recognized in international environmental law, ${ }^{66}$ the principle of non-regression and progressive realization is relatively new in an international environmental law. This principle is also inspired by international human rights law, 'requiring that norms which have already been adopted by States not be revised, if this implies going backwards on the subject of standards of protection of collective and individual rights'. ${ }^{67}$

Throughout the agreement it is elucidated that environmental access rights are rooted in the 'right of every person of present and future generations to live in a healthy environment and to sustainable development'. ${ }^{68}$ In turn, this right is aimed at the achievement of sustainable development 'comprising three dimensions - social, economic and environmental - in a balanced and integrated manner' ${ }^{69}$ The RAEAR portrays sustainable development ${ }^{70}$ as an overarching principle with several dimensions, ${ }^{71}$ implying - as Sands and colleagues point out - other closely related principles such as intergenerational equity, sustainable use, equitable development and integration. ${ }^{72}$

In addressing regional peculiarities, the RAEAR associates environmental protection with equality. At the heart of the protection, there is the need for 'sustained and inclusive economic growth, social development, environmental protection and eradication of poverty and hunger'. ${ }^{73}$ The cultural dimension of environmental rights reverberates also in the preamble which appeals to 'the multiculturalism of the Latin America and the Caribbean region and of their peoples'. ${ }^{74}$ Nevertheless, the text omits specific references to land rights, cultural

\footnotetext{
${ }^{64} \mathrm{ibid}$ art 3 . The previous text also contained the principle of cooperation, but it was deleted from the final version. See ECLAC 'Text Compiled by the Presiding Officers Incorporating the Language Proposals from the Countries on the Preliminary Document onthe Regional Agreement on Access to Information, Participation and Justice in Environmental Matters in Latin America and the Caribbean, Sixth Version' UN Doc LC/L.4059/Rev.5 (13 April 2017) (Preliminary Document RAEAR, Sixth Version).

${ }^{65}$ In the matter of Viviana Gallardo et al., Advisory Opinion No. G 101/81, Inter-American Court of Human Rights Series A (13 November 1981) para 16.

66 On accountability in international environmental law, see, e.g., M Fitzmaurice, 'International Responsibility and Liability' in D Bodansky, J Brunnée and E Hey, The Oxford Handbook of International Environmental Law (Oxford University Press 2007) 1010, 1014.

67 IUCN, 'Non-Regression Principle Knowledge Forum' <https://www.iucn.org/content/non-regressionprinciple-knowledge-forum>; M Peña Chacon (ed), El Principio de No Regresión Ambiental en Iberoamérica (IUCN 2015).

${ }^{68}$ RAEAR (n 55) art 1.

69 ibid preamble.

${ }^{70}$ On the principle of sustainable development, see, e.g., V Lowe, 'Sustainable Development and Unsustainable Arguments' in A Boyle and D Freestone (eds), International Law and Sustainable Development: Past Achievements and Future Challenges (Oxford University Press 1999) 19.

${ }^{71}$ UNGA 'The Future We Want' UN Doc A/RES/66/288 (11 September 2012) para 49.

${ }^{72}$ P Sands, J Peel and R MacKenzie, Principles of International Environmental Law (3rd edn, Cambridge University Press 2012) 206-217.

${ }^{73}$ RAEAR (n 55) preamble.

${ }^{74} \mathrm{ibid}$. A previous version, recital 19 of the preamble referred to the 'cosmovisions of its peoples'. See Preliminary Document RAEAR, Sixth Version (n 64) preamble, para 19.
} 
rights or FPIC, ILO Convention No. $169^{75}$ or the 2007 UN Declaration on Indigenous Rights or the 2016 American Declaration on the Rights of Indigenous Peoples. ${ }^{76}$ This is a missed opportunity to incorporate direct references to this legal framework and the IACtHR jurisprudence on indigenous rights, as discussed in Section $2 .{ }^{77}$

Thus, the main drivers behind the recognition of rights are 'sustainability' and the granting of 'environmental access rights for everyone'. ${ }^{78}$ As for sustainability, the RAEAR stresses the sustainable use of natural resources. With regard to accessibility, it emphasizes that constraints to access or the lack of suitable means undermines the exercise of environmental access rights. The agreement further calls on States to reinforce capacity building and promote environmental education ${ }^{79}$ guaranteeing equality in environmental protection. ${ }^{80}$ The RAEAR leaves intact States' freedom to regulate access rights in an incremental manner, as

[n] o provision in the present Agreement shall limit or repeal other more favourable rights and guarantees set forth, at present or in the future, in the legislation of a State Party or in any other international agreement to which a State is party, or prevent a State Party from granting broader access to environmental information, public participation in the environmental decision-making process and justice in environmental matters. ${ }^{81}$

The role of environmental defenders and NGOs is acknowledged as follows: "[e]ach Party shall guarantee an enabling environment for the work of persons, associations, organizations or groups that promote environmental protection, by recognizing and protecting them. ${ }^{82}$

The three limbs of protection are further elaborated in specific, inter-related articles. Essentially, access to environmental information is perceived as a basic right that enables citizens to effectively exercise public participation in environmental decision making and access to environmental justice.

\subsection{Access to environmental information}

Articles 5 and 6 deal with access to environmental information and the generation and dissemination of environmental information, respectively. Not surprisingly, the definition of environmental information laid down in Article 2 resembles what is provided for in the Aarhus Convention. ${ }^{83}$ Likewise, the non-exhaustive list of environmental information that could be accessed comprises 'any information that is written, visual, audio, electronic or recorded in any other form, regarding the state of the environment and its elements and natural resources', including also 'information related to environmental risks and any possible adverse impacts affecting or likely to affect the environment and health, as well as to environmental protection

\footnotetext{
${ }^{75}$ International Labour Organization Convention No. 169 (adopted 27 June 1989, entered into force 9 May 1991) 28 ILM 1382 (ILO Convention No. 169). Ecuador suggested the inclusion of a reference to the ILO Convention No. 169 , but this was not adopted.

${ }^{76}$ UNGA 'Declaration on the Rights of Indigenous Peoples' UN Doc A/RES/61/295 (2 October 2007).

${ }^{77}$ Awas Tingni (n 35).

${ }^{78}$ RAEAR (n 55) art 1.

79 ibid art $10(\mathrm{~d})$.

80 ibid preamble, recital 18 .

81 ibid art 4(7).

82 ibid art 4(6).

${ }^{83}$ P Oliver, 'Access to Information and to Justice in EU Environmental Law: The Aarhus Convention' (2013) 36

Fordham International Law Journal 1423.
} 
and management'.84

Under this pillar, the RAEAR puts in place certain obligations for the State parties in passive and active ways. ${ }^{85}$ Passively, States are obliged to provide environmental information when requested under the right to access to environmental information. The RAEAR requires each party to guarantee the public's right of access to environmental information in its 'possession, control or custody, in accordance with the principle of maximum disclosure'. ${ }^{86}$ The object of the obligations concerns environmental information, even if it is not labelled as such. Regarding conditions for the delivery of environmental information, competent authorities should respond to requests for environmental information as quickly as possible, but 'within a period not longer than thirty business days from the date of receipt of the request, or less if so stipulated in the domestic legislation of any of the States parties' ${ }^{87}$ Several grounds for refusing access to environmental information along similar lines to those of the Aarhus Convention are specified in the agreement. ${ }^{88}$ The grounds to refuse environmental information should be interpreted restrictively and, in any case, remedies against the decision should be made available.

In addition, each party should actively collect and disseminate environmental information motu proprio as a condition for transparency. ${ }^{89}$ The agreement requires each party to guarantee 'that the competent authorities generate, collect, publicize and disseminate environmental information relevant to their functions in a systematic, proactive, timely, regular, accessible and comprehensible manner, and periodically update this information' ${ }^{90}$

The RAEAR makes several references to specific areas of environmental protection (termed 'environmental information systems'), such as those related to information on EIA processes and on other environmental management instruments. ${ }^{91}$ These include (in an openended list) information concerning the texts of treaties and international agreements, environmental laws, regulations and administrative acts, reports on the state of the environment, scientific, technical or technological reports, studies and information on environmental matters produced by academic and research institutions, as well as the dissemination of information from research and studies on climate change. ${ }^{92}$ To emphasize the enforcement of environmental legislation, Article 6 also includes information on the imposition of administrative sanctions. ${ }^{93}$ A specific provision is made concerning the establishment of a pollutant release and transfer register covering air, water, soil and subsoil pollutants, and waste. $^{94}$

The RAEAR also contemplates inter-State obligations in the dissemination of environmental information arising from due diligence, ${ }^{95}$ such as the obligation to notify other States:

\footnotetext{
${ }^{84}$ RAEAR (n 55) art 2(c).

85 ibid arts 5-6.

${ }^{86}$ ibid art 5(1).

87 ibid art 5(12).

88 ibid art 6(4).

89 ibid art 5.

90 ibid art 6(1).

91 ibid art 6(3).

92 ibid art 6(3)(a), (b), (f) and (g), respectively. During the negotiations of the draft agreement, this was the proposal put forward by Trinidad and Tobago.

93 ibid art 6(3)(j).

94 ibid art 6(4).

${ }^{95}$ ILA Study Group on Due Diligence, 'First Report' (2014); and 'Second Report' (2016). Both reports can be found at: <http://www.ila-hq.org/en/study-groups/index.cfm/cid/1045>.
} 
[e] ach Party shall guarantee that in the case of an imminent threat to public health or the environment, it shall immediately disclose and disseminate through the most effective means all pertinent information in the possession of the competent authority that could help the public take measures to prevent or limit potential damage. Each Party shall use the mechanisms available to develop and implement an early warning system. ${ }^{96}$

Independent oversight mechanisms are also addressed in the agreement, which mandates that

[e] ach Party shall establish or designate one or more impartial entities or institutions with autonomy and independence to promote transparency in access to environmental information, to oversee compliance with rules, and monitor, report on and guarantee the right of access to information. Each Party may consider including or strengthening, as appropriate, sanctioning powers within the scope of the responsibilities of the aforementioned entities or institutions. ${ }^{97}$

While the wording of the articles seems strong, implementation of the provisions will not be straightforward. Disagreement has already arisen during the negotiations as to the inclusion of public, private and public-private enterprises 'with functions of a public nature' under the definition of public authorities. ${ }^{98}$

\subsection{Public participation in the environmental decision-making process}

Accountability in the implementation of environmental law and transparency in environmental decision making are two burning questions in LAC. The right to public participation as regulated by the RAEAR presents a challenge to existing regulatory regimes as parties will need to provide for public participation in various environmental decision-making spheres. With regard to this right, the RAEAR draws on the work of the OAS on the freedom of expression, as well as the 2010 Inter-American Model Law on Access to Public Information. ${ }^{99}$

Article 7 tackles public participation in decision making in environmental matters by first stating generally that '[e]ach Party shall ensure the public's right to participation and for that purpose shall commits to implement open and inclusive participation in mechanisms for environmental decision-making based on domestic and international normative frameworks'. ${ }^{100}$ The text goes on to detail the various domains for public participation, which

\footnotetext{
${ }^{96}$ RAEAR (n 55) art 6(5).

97 ibid art 18.

${ }^{98}$ See Preliminary Document RAEAR, Sixth Version (n 64), which included for example the list of 'public, private and public-private enterprises with functions of a public nature' under entities that were required to make information with environmental content publicly accessible. However, Argentina proposed to include only enterprises 'with functions of a public nature that provide public services', whereas Uruguay, Antigua and Barbuda, Grenada, Jamaica, Saint Kitts and Nevis, Saint Vincent and the Grenadines, Trinidad and Tobago, Costa Rica, El Salvador, Guatemala, Honduras, Panama, Dominican Republic and Brazil suggested the inclusion of the 'list of State bodies or entities that perform public functions or provide public services in possession of information with environmental content that should be publicly accessible'.

${ }^{99}$ E Lanza, 'The Right to Access to Public Information in the Americas: Specialized Supervisory and Enforcement Bodies. Thematic report included in the 2014 Annual Report of the Office of the Special Rapporteur for Freedom of Expression of the Inter-American Commission on Human Rights' (March 2015) $<$ http://www.oas.org/en/iachr/expression/docs/reports/access/thematic\%20report\%20access\%20to\%20public\%2 0information\%202014.pdf>. OAS, 'AG/RES. 2607 (XL-O/10) Model Inter-American Law on Access to Public Information’ (2010)<https://www.oas.org/dil/AG-RES_2607-2010_eng.pdf $>$.

${ }^{100}$ RAEAR (n 55) art 7(1).
} 
comprise decision-making processes 'with respect to projects and activities ... that may potentially have a significant impact on ... the environment or the conservation, use and management of natural resources, and particularly those subject to environmental impact assessment and, as appropriate, in other environmental permitting processes'. ${ }^{101}$ States undertake 'to implement[] all necessary measures to facilitate participation in environmental matters of public interest such as environmental land-use planning, policies, strategies, plans, programmes and regulations'. ${ }^{102}$ Read together, it can be seen that whereas Article 7(1) contains core elements of the right, a subset of rules is set out in Articles 7(2) and 7(3).

Some comments on the implementations are in order. To start with, public participation takes place essentially in three realms: decision making concerning EIAs and permitting processes, the adoption of plans and programmes and law-making. In general, public participation in environmental decision making is scattered across different regimes, such as permitting processes. Thus, the specific content of the right will depend on each State's legislation. Participation in decision making turns is key in some areas, such as EIA. In relation to participation in environmental law-making in particular, the agreement suggests that it should take place through various forms of institutionalized participation that involve stakeholders, including online participation. Internet access is considered as the main means to widen participation in LAC; however, gaps in access to internet have been observed across the different countries. ${ }^{103}$

While agreement does not regulate participation in law-making, it attempts to guarantee a level playing field for public participation in a series of decision-making processes. The RAEAR covers broadly the participation in permitting processes (scattered throughout national legislation) and in EIA. Mapping the means for participation in different administrative processes will be a task for each State in accordance with their respective public law systems.

The agreement sets out specific standards for effective participation, namely: previous dissemination of relevant information in a timely, clear and comprehensive manner; participation at an early stage; the possibility of attending hearings and presenting observations; reasonable timeframes and notification of the grounds and reasons underlying the decision once it has been made, among others. ${ }^{104}$

The RAEAR further calls for the participation of indigenous peoples, a group traditionally marginalized from decision making processes. This is also true with regard to other vulnerable groups, such as women. However, although gender is referred to as a condition of vulnerability in Article 7(10), it is not considered a crosscutting issue. ${ }^{105}$

Overall, if correctly implemented, this right can widely influence domestic procedures for the granting of permits and the drafting of new environmental legislation.

\subsection{Access to justice in environmental matters}

This is a particularly relevant pillar in light of the difficulties experienced in practice in LAC. Debates surrounding access to environmental justice have been followed closely by stakeholders. ${ }^{106}$ The definition of environmental justice in the RAEAR refers to 'access to

\footnotetext{
101 ibid art 7(2).

102 ibid art 7(3).

${ }^{103}$ ECLAC, 'Estado de la banda ancha en América Latina y el Caribe 2016' (ECLAC 2016).

${ }^{104}$ RAEAR (n 55) art 8 (numerals 5-7).

${ }^{105}$ Chile proposed to introduce 'gender parity' in art 8(13) and a 'gender approach' in art 10(8). See Preliminary Document RAEAR, Sixth Version (n 4).

106 Virtual inter-sessional meeting held on 31st January 2017. Discussion of the article on access to environmental justice with experts and stakeholders; ECLAC, 'History of the Regional Agreement' $<$ https://www.cepal.org/en/subsidiary-bodies/acuerdo-regional-acceso-la-informacion-la-participacion-publicaacceso-la-justicia/history-regional-agreement $>$.
} 
judicial and administrative mechanisms to challenge and appeal' environmental decisions. ${ }^{107}$ Acknowledging the difficulties in obtaining judicial review, the agreement attempts to guarantee equal conditions for the disputing parties. ${ }^{108}$

This right is intrinsically connected to access to information, which is a prerequisite for exercising the right to initiate a lawsuit. Article 8(2) regulates the right to challenge inter alia 'any decision, action or omission related to the access to environmental information' or 'to public participation in the decision-making process regarding environmental matters'. ${ }^{109}$ More generally, the article refers to the possibility of seeking judicial review of 'any decision, action or omission that affects or could affect the environment adversely or violate laws and regulations related to the environment'. ${ }^{110}$ In any case, disputing parties should inter alia have the possibility of ordering precautionary and interim measures, and avail of mechanisms to execute and enforce judicial and administrative decisions in a timely manner as well as mechanisms for redress. ${ }^{111}$

As previously noted, States may provide clear indications of the remedies available wherever the exercise of rights to access to environmental information or to public participation are denied. Some LAC countries are more prone to introducing changes in the legislation on access to environmental justice, such as Costa Rica or Chile which have already put in place environmental courts.

Several improvements in access to environmental justice have occurred in recent years in the region, but many shortcomings still exist. Rights-based actions and procedures have advanced the case for environmental justice in LAC. As a result, different procedural channels can be used before the courts to protect rights at stake with the aim of obtaining orders requiring action or ordering abstention (staying certain harmful actions). The specialization and the existence of environmental courts and tribunals may help in advancing the cause of environmental justice. ${ }^{12}$ These courts and tribunals are in a better position to adjudicate environmental claims as they focus on environmental law. Furthermore, environmental courts and tribunals are assisted by scientific experts who may provide evidence on environmental harm.

The main barriers concerning the access to environmental justice faced in LAC and that the RAEAR may encounter in its implementation relate to the weakness of the rule of law, costs, the language of the information, the complexity of the procedures, the lack of a proper international status for NGOs and the limited accountability of corporations for environmental damages.

Access to environmental justice at the domestic level requires respect for the rule of law, including a proper checks-and-balances system, which might be difficult to achieve in some LAC countries. The importance of the concept of 'public interest' for environmental litigation before human rights courts in the region resides in the possibility to obtain

\footnotetext{
107 RAEAR (n 55) art 8(2). Compare the actual definition with an earlier definition, which referred to 'the possibility that legal conflicts of an environmental nature receive from the jurisdictional bodies expeditious and full settlement, which, to the degree that it can be achieved by the courts of justice, will contribute to environmental protection and the promotion of sustainable development'. However, some negotiating States (Argentina, Uruguay, Paraguay, Saint Lucia and Colombia) suggested deleting this definition. See Preliminary Document RAEAR, Sixth Version (n 64).

${ }^{108}$ RAEAR (n 55) art 8.

109 ibid art 8(2)(a-b).

110 ibid art $8(2)(\mathrm{c})$.

111 ibid art 8(3)(d), (f) and (g).

112 Regional Judicial Colloquium for Latin America and the Caribbean, Constitutions, Environment, and Human Rights: Practice and Implementation (22-23 May 2017) $<$ https://wedocs.unep.org/bitstream/handle/20.500.11822/20772/final_programme_regional_colloquium_human _rights_brasilia.pdf? sequence $=1 \&$ isAllowed $=\mathrm{y}>$.
} 
international oversight by an intergovernmental body monitoring compliance (such as the CIC), which reinforces the rule of law.

In relation to the costs, socio-economic inequalities in access to environmental justice in LAC are stark. ${ }^{113}$ The RAEAR specifies that to 'give effect to the right of access to justice, each Party shall meet the needs of persons or groups in vulnerable situations by establishing support mechanisms, including, as appropriate, free technical and legal assistance'.114 Likewise, States should establish measures to minimize or eliminate barriers to access to justice. ${ }^{115}$ To ensure appropriate access to justice, the RAEAR further provides for 'the use of interpretation or translation of languages other than the official languages when necessary for the exercise of that right'. ${ }^{116}$

The complexity of environmental proceedings is a common feature in LAC. Litigating an environmental case usually requires expert knowledge and evidence of environmental harm. Procedural entanglements make it difficult to get effective access to redress. To alleviate this, the RAEAR includes some commitments regarding procedural aspects. ${ }^{117}$

The role of NGOs in seeking environmental justice in LAC is essential, particularly in transboundary pollution cases. Environmental conflicts are frequent in the region, but only those which have received support from NGOs have become more visible. A draft version of the agreement defined them as NGOs 'promoting environmental protection and meeting any requirements under national law which shall be deemed to have an interest' and encouraging cooperation. ${ }^{118}$ The RAEAR, however, only incidentally mentions them in the definitions and in other parts of the text. ${ }^{119}$

Another pending issue is the possibility of also involving corporations in the procedure for compliance with access rights, an issue that was widely discussed during the negotiations. ${ }^{120}$ Quasi-judicial forums for environmental justice, such as the Latin American Water Tribunal, are regarded by individuals and associations as a fairer means to achieve justice, mainly because there is the possibility of calling corporations and not only States to the hearings. ${ }^{121}$

The RAEAR commits parties to adhere to principles of due process, such as effectiveness, publicity and impartiality, and to guarantee broad legal standing in defence of the environment. Divergent opinions arose during the negotiations as to whether this access should comprise only jurisdictional bodies or also administrative bodies. ${ }^{122}$ Ultimately, the RAEAR also encourages access to administrative bodies such as ombudsmen and alternative dispute resolution is encouraged. More interestingly, the RAEAR advances on several procedural issues, such as: mechanisms to execute and enforce judicial and/or administrative rulings and decisions; mechanisms for redress, including restitution, restoration, compensation and assistance for affected persons; precautionary, interim and oversight measures to

\footnotetext{
${ }^{113}$ D Negro, 'Poverty, Inequality, Vulnerable Groups and Access to Justice' in OAS (ed), Inequality and Social Inclusion in the Americas (2nd edn, OAS 2011) 135.

114 RAEAR (n 55) art 8(5).

115 ibid art 8(4)(a).

116 ibid art 8(4)(d).

117 ibid art 8(4)(a-c).

${ }^{118}$ See Preliminary Document RAEAR, Sixth Version (n 64), in which the text spelled out the obligation of the States to 'cooperate, as applicable, with ... non-governmental entities'.

${ }^{119}$ RAEAR (n 55) preamble and art 10(6).

${ }^{120}$ See Preliminary Document RAEAR, Sixth Version (n 64); the draft stated that in terms of generation and dissemination of environmental information, '[i]n accordance with their respective capacities, the Parties shall encourage public and private companies, particularly large companies, to prepare sustainability reports that reflect their social and environmental performance'.

${ }^{121}$ MB Olmos Giupponi, 'Transnational Environmental Law and Grass-Root Initiatives: The Case of the Latin American Water Tribunal', Volume 5, Issue 1, April 2016 Transnational Environmental Law, pp. 145-174.

122 RAEAR (n 55) art 2.
} 
safeguard, prevent, halt and rehabilitate or mitigate damage to the environment; and measures to facilitate the production of evidence of environmental damage, including, where appropriate, strict liability. ${ }^{123}$

Overall, the RAEAR attempts to remove obstacles that may hinder the effective implementation considering, particularly, peoples and groups in vulnerable situations, by advocating for reasonable costs and waivers of costs for applicants in a vulnerable situation or facing special circumstances. ${ }^{124}$ As an innovation, the RAEAR foresees the resort to alternative dispute resolution mechanisms by stating that '[e]ach Party shall promote, where appropriate, alternative dispute resolution mechanisms in environmental matters, such as mediation, conciliation or other means that allow such disputes to be prevented or resolved'. ${ }^{125}$

To provide further legal protection, Article 9 mandates governments to adopt measures to 'prevent, investigate and prosecute attacks, threats, coercions or intimidations that any person or group may suffer while exercising the rights guaranteed by agreement' and to 'take adequate and effective measures to recognize, protect and promote all the rights of human rights defenders in environmental matters, including their right to life, personal integrity, freedom of opinion and expression, peaceful assembly and association, and free movement, as well as their ability to exercise their access rights, taking into account its international obligations in the field of human rights, its constitutional principles and the basic concepts of its legal system'. ${ }^{126}$ This is a sorely needed provision, as many environmentalists have faced threats to their lives and some have been killed in recent years. ${ }^{127}$

The RAEAR is expected to improve access to environmental justice in the region. However, while the agreement may point at obstacles encountered in the access to justice, it cannot solve problems that stem from national systems.

\section{PROPOSALS TO ENHANCE THE IMPLEMENTATION OF THE AGREEMENT}

Implementation is the major challenge for the RAEAR. Translating the norms into action in domestic jurisdictions will be difficult, first, because a certain expertise in environmental access rights is necessary to set up the various compliance processes. ${ }^{128}$ Second, implementation requires the knowledge of a wide range of disciplines, and strengthening cooperation between natural and social sciences. Third, effective implementation will not be achieved simply by tweaking national legislation; it will require a major overhaul of some legal systems. Implementation may be relatively easy to achieve for environmental frontrunners such as Costa Rica, which enacted a very comprehensive law protecting the environment. ${ }^{129}$ In other countries, obstacles to implementation such as lack of appropriate resources may water down the wording of the agreement. ${ }^{130}$

The RAEAR provides for several mechanisms aimed at making it effective, as analysed below. In addition, the experience of the Aarhus Committee on environmental access rights and the practice of the IAHRS with regard to the safeguarding of related human rights could help in the implementation of the agreement.

\footnotetext{
123 ibid art $8(4)(\mathrm{d}-\mathrm{g})$.

124 ibid art 4(18).

125 ibid art $8(7)$.

126 ibid art $9(1-3)$.

${ }^{127}$ Among the high-profile cases involving environmental defenders, there is Chico Mendes, the leader of a forest conservationist campaign in the Amazon, who was killed by the police in 1998, and later become a symbol of the global environmental movement. More recently, Berta Caceres, a Honduran environmental activist opposing the construction of a dam in indigenous territory, was murdered.

${ }^{128}$ RAEAR (n 55) art 10-11.

129 Organization of the Environment Act (Law N 7554).

${ }^{130}$ RAEAR (n 55) art 4(8).
} 


\subsection{Guaranteeing the effectiveness of the RAEAR}

Various tools and mechanisms are used to ensure effective implementation of the agreement. First, the RAEAR contains an interpretation rule according to which each party shall seek to adopt 'the most favourable interpretation for the full enjoyment of and respect for the access rights'. ${ }^{131}$ The RAEAR further includes specific provisions on capacity building ${ }^{132}$ and cooperation, ${ }^{133}$ acknowledging the need for appropriate infrastructure to implement the agreement. Emphasis is thus put on critical areas, such as environmental education and training in environmental access rights. The RAEAR also contains a specific provision on the implementation of the agreement, stating that each party 'to the extent of its ability and in accordance with its national priorities, commits to provide the resources for national activities that are needed to fulfil the obligations derived from the present Agreement'. ${ }^{134}$ In addition, the ECLAC will operate a 'clearing house on access rights' (in a similar fashion as the mechanism instituted under the Aarhus Convention) to include, inter alia, legislative, administrative and policy measures, codes of conduct and good practices. ${ }^{135}$ A voluntary fund, made up by contributions by the parties to support the implementation of the agreement, is also foreseen in the RAEAR. ${ }^{136}$

The Conference of the Parties $(\mathrm{CoP})^{137}$ is to 'examine and promote the implementation and effectiveness' and create other subsidiary bodies. ${ }^{138}$ The institutional set-up of the agreement comprises intergovernmental bodies to be created after the entry into force. ${ }^{139}$ At its first meeting, the CoP is to 'discuss and adopt by consensus its rules of procedure, including the modalities for significant participation by the public'. ${ }^{140}$ This may create an initial legal vacuum in ensuring compliance with the RAEAR. ${ }^{141}$ The CoP is at the centre of the noncompliance procedures: States will report back on the policies and measures adopted to implement the agreement and the activities conducted with the public. ${ }^{142}$

A subsidiary body called the Committee to support Implementation and Compliance $(\mathrm{CIC})^{143}$ is envisaged to review compliance with the agreement and to formulate recommendations. ${ }^{144}$ The CIC's main role is 'to promote application and support the Parties with implementation of the Agreement'. ${ }^{145}$ The CIC is to be of 'a consultative and transparent nature, non-adversarial, non-judicial and non-punitive and shall review compliance of the provisions of the Agreement and formulate recommendations', in accordance with rules of procedure to be established by the CoP. ${ }^{146}$

Therefore, the CoP is in charge of taking stock of the achievements of the compliance mechanism, and tasked with issuing rules to facilitate the application by public authorities and

\footnotetext{
131 ibid.

132 ibid art 10.

133 ibid art 11.

134 ibid art 13.

135 ibid art 12.

136 ibid art 14.

137 ibid arts 15-17.

138 ibid art 15.

139 ibid arts $12-16$.

140 ibid.

141 ibid art 15.

142 ibid art 15(4) (b-d).

143 ibid art 18.

144 ibid art 15(4)(a), 17, 18 and 20.

145 ibid art 18(1).

146 ibid art 18(2).
} 
fostering the participation of stakeholders in the compliance system. ${ }^{147}$ In the non-compliance procedure, 'the national capacities and circumstances of the Parties' shall be taken into account. ${ }^{148}$ This may lead to a 'differentiated speed' system.

Finally, the settlement of disputes regarding the interpretation or application of the Agreement will take place through by negotiation or by any other means of dispute settlement (namely judicial settlement before the ICJ and international arbitration). ${ }^{149}$

\subsection{Building on the practice of the Inter-American human rights system}

The agreement reflects IACtHR jurisprudence relating to environmental protection, which adds a regional dimension. Access to environmental information has been upheld in several cases by the Court, which has endorsed the right in the context of activities of exploration and exploitation of natural resources in the territory of indigenous communities. ${ }^{150}$ Similarly, the removal of language barriers to access to justice has been underlined by the IACHR in several environmental cases, such as in the Belo Monte Dam conflict affecting several indigenous peoples in the Amazon. On that occasion, the IACHR issued an order to stay the construction of the dam until information about the project and the social and environmental impact assessment were made available in an accessible format, 'including translation into the respective indigenous languages'. ${ }^{151}$

In the Advisory Opinion on Human Rights and the Environment, the IACtHR identified specific obligations for States to respect environmental access rights in relation to the obligations of States in safeguarding the environment. ${ }^{152}$ In the Court's view, access to information ${ }^{153}$ under Article 13 of the ACHR emanates from governments' obligations of transparency in a democratic context; ${ }^{154}$ particularly with regard to 'activities and projects that could have an environmental impact' ${ }^{155}$ In its analysis, the Court relied on the case law of the ECtHR in relation to access to environmental information in the event of risk ${ }^{156}$ and the African Commission of Human Rights concerning access to environmental information. ${ }^{157}$ The IACtHR expressly referred to Principle 10 and the "multiple universal and regional treaties that include the obligation of access to information in environmental matters', ${ }^{158}$ referring also to the adoption of the RAEAR ${ }^{159}$ Citing the Bali Guidelines, the Court emphasized that access to environmental information must be affordable, effective and timely. ${ }^{160}$ Moreover, the Court defined 'active transparency' as encompassing 'the duty of States to publish informally relevant and necessary information on the environment, in order to guarantee human rights under the Convention, such as information on environmental quality, environmental impact on health and factors that influence it, as well as information about legislation and policies and

\footnotetext{
147 ibid art 18(2).

148 ibid art 17(2) and 4.

149 ibid art 19.

${ }^{150}$ Case of the Kichwa Indigenous People of Sarayaku v. Ecuador, Merits and Reparations, Judgment, InterAmerican Court of Human Rights Series C No 242 (27 June 2012) para 230.

${ }^{151}$ IACHR, Precautionary Measures PM 382/10 - Indigenous Communities of the Xingu River Basin, Pará, Brazil.

152 Advisory Opinion 23/17 (n 41) paras 211-241.

153 ibid paras 213-215.

154 ibid para 213 .

155 ibid.

${ }^{156}$ Caso Di Sarno et al v Italy, App No 30765/08 (ECtHR, 10 January 2012) para 107.

157 ibid para 215; Social and Economic Rights Action Center/Center for Economic and Social Rights v Nigeria, Comm 155/96, 15th ACHPR AAR Annex V (2000-2001) para 53.

${ }^{158}$ Advisory Opinion 23/17 (n 41) para 216.

159 ibid para 218.

160 ibid para 220.
} 
advice on how to obtain that information'. ${ }^{161}$

The Court went on to analyse restrictions to the access to information, asserting that those are admissible 'as long as they are previously established by law, they meet an objective allowed by the American Convention ("respect for the rights or reputation of the rest' or 'the protection of national security, public order or public health or morals") ${ }^{162}$, and are necessary and proportional in a democratic society'. ${ }^{163}$ The Court thus confirmed the principle of maximum disclosure, ascertaining the 'presumption that all information is accessible, subject to a restrictive system of exceptions'. ${ }^{164}$ This results in a reversion of the burden of proof which rests with the State; the burden of justification of any refusal of access to information falls on the body from which the information was requested. ${ }^{165}$

Public participation in environmental decision making was considered by the Court as a procedural right ${ }^{166}$ enshrined in Article 23(1)(a) of the ACHR. ${ }^{167}$ The Court examined this right in the context of FPIC of indigenous peoples with regard to projects that affect them. ${ }^{168}$ The Court asserted that 'participation represents a mechanism to integrate the concerns and knowledge of citizens in public policy decisions that affect the environment'. ${ }^{169}$ The Court relied on the ECtHR's case law, ${ }^{170}$ and on the right to public participation as enshrined in various regional and international environmental legal instruments, including the Stockholm Declaration and the Rio Declaration and the World Charter of Nature. ${ }^{171}$ Regarding the timing of public participation, the Court asserted that the State must guarantee opportunities for effective participation at all stages of the decision-making process and inform the public about opportunities for participation. ${ }^{172}$

In the Court's view, access to environmental justice is rooted in the general right to access to justice, which constitutes a peremptory international norm. ${ }^{173}$ The Court held that States have undertaken to provide effective judicial remedies to victims of human rights violations (Article $25 \mathrm{ACHR}$ ), which must be substantiated in accordance with the rules of due process of law (Article 8(1) ACHR), within the general obligation of the States guarantee the free and full exercise of the rights recognized by the Convention to every person under their jurisdiction (Article 1(1) ACHR). ${ }^{174}$ Accordingly, access to environmental justice enables individuals to ensure that environmental standards are applied, and offers a remedy to any violation of human rights caused by non-compliance with environmental norms. ${ }^{175}$ The Court also affirmed that environmental access rights are interrelated as access to justice guarantees the full realization of the rights to public participation and access to information. The Court reminded that various international environmental legal instruments expressly provide for the obligation to guarantee access to environmental justice. It specifically mentioned Principle 10

\footnotetext{
161 ibid para 221-222223.

162 American Convention on Human Rights (adopted 22 November 1969, entered into force 18 July 1978) 1144 UNTS 123 art 13.

${ }^{163}$ Advisory Opinion 23/17 (n 41) para 224.

164 ibid.

165 ibid.

166 ibid para 226.

167 ibid para 227.

${ }^{168}$ B Olmos Giupponi, 'Free, Prior and Informed Consent (FPIC) of Indigenous Peoples before Human Rights Courts and International Investment Tribunals: Two Sides of the Same Coin?' (2018, fc) International Journal on Minority and Group Rights.

169 Advisory Opinion 23/17 (n 41) para 228.

170 ibid para 229.

171 ibid para 230 .

172 ibid para 232.

173 ibid para 233.

174 ibid.

175 ibid para 234.
} 
of the Rio Declaration, which stipulates that access to procedures and compensation for damages must be effective. ${ }^{176}$ Likewise, the Court referred to compensation for environmental damage as established in Principle 23 of the World Nature Charter and in Agenda 21. ${ }^{177}$ In light of these considerations, the Court that States are obliged to guarantee access to environmental justice in accordance with the rules of due process; to challenge any rule, decision, act or omission of public authorities that may contravene environmental law obligations; to ensure the full realization of the other procedural rights; and to remedy any human rights violations resulting from non-compliance with environmental law obligations. ${ }^{178}$

The Court has thus ascribed environmental access rights a procedural nature, encompassing different levels of protection. Having clearly established the interrelation between the different environmental access rights, the Court can rely upon the advisory opinion to enforce environmental access rights in the future. According to the Court, the reach of advisory opinions goes beyond the States which are parties to the ACHR, and includes all OAS member States. ${ }^{179}$

Further to the case law, there are other ways to harness the protection of environmental access rights through the IAHRS. For instance, another relevant tool is the interpretative methods used by the Court. Pursuant to Article 29(1) of the ACHR, the Court can interpret other human rights treaties and treaties with an impact on human rights. As stated above, the RAEAR is considered a human rights treaty.

Finally, the consistent interpretation and the conventionality control doctrines will further reinforce the application of the RAEAR. ${ }^{180}$ The dialogue between national courts (particularly supreme or constitutional courts) has been strengthened via the principle of interpretación conforme (consistent interpretation) and control de convencionalidad (conventionality control). The first principle requires that domestic laws be interpreted in conformity with the ACHR and related IACtHR case law, reducing the margin of appreciation of national authorities. ${ }^{181}$ Through the second mechanism, domestic courts monitor the lawfulness of State parties' measures in light of the obligations assumed under the ACHR. ${ }^{182}$

\subsection{Tapping into the experience of the Aarhus Committee}

In Europe, the Aarhus Convention was backed by the European Union (EU), which enacted directives to fulfil the obligations, giving rise to two channels to ensure compliance: through EU institutions (Commission and Court of Justice) and through the Aarhus Convention

\footnotetext{
176 ibid para 235 .

177 ibid para 236.

178 ibid para 237.

${ }^{179}$ See, e.g., Juridical Condition and Rights of the Undocumented Migrants, OC-18/03, Inter-American Court of Human Rights, Advisory Opinion OC-18/03, Inter-American Court of Human Rights Series A No 18 (17 September 2003); see also A Bianchi, 'Human Rights and the Magic of Jus Cogens' (2008) 19 European Journal of International Law 491.

${ }^{180}$ G Candia, 'Comparing Diverse Approaches to the Margin of Appreciation: The Case of the European and the Inter-American Court of Human Rights' (9 March 2014).

${ }^{181}$ A Dulitzky, 'La Aplicación de los Tratados sobre Derechos Humanos por los Tribunales Locales: Un Estudio Comparado' in M Abregú and C Courtis (eds), La Aplicación de los Tratados sobre Derechos Humanos por los Tribunales Locales (Del Puerto 2004) 33.

182 IACtHR, Control de Convencionalidad, Cuadernillo de Jurisprudencia de la Corte Interamericana de Derechos Humanos $N^{o} 7$ (IACtHR 2015) <http://www.corteidh.or.cr/tablas/r33825.pdf>. See A Dulitzky, 'An Inter-American Constitutional Court? The Invention of the Conventionality Control by the Inter-American Court of Human Rights' (2015) 50 Texas International Law Journal 45.
} 
Compliance Committee (ACCC), which was set up in 2002 to oversee parties' compliance. ${ }^{183}$ At this point, two considerations are in order. First, there is no comparable organization for regional integration in the Americas. Second, the ACCC has strongly criticized the EU's noncompliance with the Convention. ${ }^{184}$

It is worth looking at the practice of the ACCC, as it may prove relevant for the functioning of the CIC. Indeed, the ACCC, established as a separate quasi-judicial body made up of independent experts, has accrued considerable experience in handling communications by members of the public. The Aarhus Convention establishes that other States and international organizations can become signatories, broadening the regional scope of the Convention and the ACCC's activities. ${ }^{185}$

Under the Aarhus system, the ACCC may examine: submissions about compliance made by parties against other parties; submissions by parties about their own compliance; referrals by the secretariat; communications put forward by members of the public (individuals, groups of individuals, organizations and groups of organizations); and submissions by the Aarhus Convention CoP. ${ }^{186}$ Statistics on compliance demonstrate that organizations (e.g. NGOs) are the more frequent users of the system. ${ }^{187}$ The architecture of the ACCC is circumscribed to monitoring compliance of the respective national legal framework with the provisions of the Convention. Thus, the ACCC cannot engage in a comprehensive analysis of the national system of environmental law. ${ }^{188}$ Moreover, the non-compliance procedure under the Aarhus Convention is not meant to be a redress procedure.

Regarding communications from the public, the traditional rule of exhaustion of domestic remedies applies to the Aarhus non-compliance procedure. ${ }^{189} \mathrm{In}$ accordance with the Convention, once the communication has been declared admissible, the State concerned is given the opportunity to make its submissions. After that, a public hearing will take place. The investigation concludes with a report on compliance alongside recommendations, which are ultimately adopted by the CoP. The findings of the ACCC are studied by the CoP, which monitors the follow up.

The case law arising from non-compliance and misapplication of the Convention provision gives a clear picture of the implementation of the Aarhus Convention. ${ }^{190}$ The Committee has set out the requirements in terms of admissibility, such as that the communications should cover the period since the entry into force of the Aarhus Convention for the State concerned, and must not be anonymous. Three main aspects concerning

${ }^{183}$ Pursuant to Article 15 of the Aarhus Convention, adopted Decision I/7 on review of compliance, establishing the Committee and electing its first members. UNECE 'Decision I/7, Review of Compliance' UN Doc ECE/MP.PP/2/Add.8 (2 April 2004).

${ }^{184}$ Aarhus Convention Compliance Committee, 'Findings and Recommendations of the Compliance Committee with regard to Communication ACCC/C/2008/32 (Part II) Concerning Compliance by the European Union' (17 March 2017) <https://www.unece.org/fileadmin/DAM/env/pp/compliance/C200832/Findings/C32_EU_Findings_as_adopted_advance_unedited_version.pdf $>$.

${ }^{185}$ The following states have signed and ratified the Aarhus Convention: Armenia (25 June 1998/1 August 2001), Kazakhstan (25 June 1998/11 January 2001), Kyrgyzstan (1 May 2001 - accession), Tajikistan (17 Jul 2001 accession) and Turkmenistan (25 Jun $1999 \quad-\quad$ accession). See $<$ https://treaties.un.org/Pages/ViewDetails.aspx?src=IND\&mtdsg_no=XXVII-13\&chapter=27\&clang=_en $>$.

${ }^{186}$ Aarhus Convention (n 12) art 18.

${ }^{187}$ UNECE, 'Compliance Committee in Numbers' < https://www.unece.org/env/pp/cc infographics.html>.

188 ACCC 'Findings and Recommendations with Regard to Communication AC $\bar{C} \mathrm{C} / \mathrm{C} / 2009 / 37$ Concerning Compliance by Belarus (adopted by the Compliance Committee on 24 September 2010)' UN Doc ECE/MP.PP/2011/11/Add.2 (12 May 2011) para 61.

189 UNECE, 'Guide to the Aarhus Convention Compliance Committee' (March 2017) $<$ http://www.unece.org/fileadmin/DAM/env/pp/compliance/CC_Guidance/Guide_to_the_ACCC_for_CC56_cle an.pdf $>$.

190 A Andrusevych, T.Alge and C Konrad (eds), Case Law of the Aarhus Convention Compliance Committee (2004-2014) (3rd edn, RACSE 2016). 
compliance are revealed in the case law: (i) the failure to provide access to environmental information; (ii) a lack of access to decision making (mainly concerning EIA processes); and (iii) obstacles to access to environmental justice. ${ }^{191}$ Another aspect that deserves attention is the follow-up of the decisions on compliance. A good practice observed consists of providing concerned States with precise indications as to the changes to be introduced to bring domestic law in line with the Aarhus Convention within a specific time frame. ${ }^{192}$

Bearing in mind the peculiarities of each region, there are some lessons to be learned from the application of the Aarhus Convention. The ACCC has established that States are under the obligation to provide for detailed regulation of public bodies' nature and functions in the fulfilment of their obligations. ${ }^{193}$ In the application of the Aarhus Convention, national judges have interpreted whether a certain entity is a public authority and therefore subject to national legislation, giving effect to the Convention and European Union Directive 2003/4 on access to environmental information. ${ }^{194}$ There is a need to define the concept of 'public authority' as happened in the case of Europe. The CIC will likely develop case law to clarify what can be considered a public authority.

In the ACCC's case law, a golden rule observed in the compliance with the obligations related to access to environmental information is that there must be a clear, transparent and consistent legal framework to make environmental information available to the public. ${ }^{195}$ To implement the Convention, the State must provide 'clear instructions on the status and obligations of bodies performing functions of public authorities, or regulating the issue of standing in cases on access to information in procedural legislation'. ${ }^{196}$ States should engage in the adoption of guidelines to facilitate the implementation of the RAEAR, as happened in Europe with the Aarhus Convention. ${ }^{197}$ To avoid the 'information hurdle' in LAC, environmental information must be made available in indigenous languages, which is a requirement for both access to environmental information and for public participation. ${ }^{198}$

In the Caribbean, many countries have appointed an Information Commissioner under their freedom of information acts, who will have an essential function in access to information. As an example of good practice, in the United Kingdom guidelines for the Information

\footnotetext{
${ }^{191}$ Aarhus Convention (n 12) art 6(2), (4) and (8).

${ }^{192}$ ACCC 'Findings and Recommendations with Regard to Compliance by Kazakhstan with the Obligations under the Aarhus Convention in the Case of Information Requested from Kazatomprom (Communication ACCC/C/2004/01 by Green Salvation (Kazakhstan))' UN Doc ECE/MP.PP/C.1/2005/2/Add.1 (11 March 2005) para 23 .

${ }^{193}$ ACCC 'Findings and Recommendations with Regard to Compliance by Armenia with Its Obligations under the Aarhus Convention in Relation to the Development of the Dalma Orchards Area (Communication ACCC/C/2004/08 by the Center for Regional Development/Transparency International Armenia, the Sakharov Armenian Human Rights Protection Center and the Armenian Botanical Society (Armenia))' UN Doc ECE/MP.PP/C.1/2006/2/Add.1 (10 May 2006) para 19.

${ }^{194}$ See, e.g., National Asset Management Agency v Commissioner for Environmental Information [2015] IESC 51.

${ }^{195}$ ACCC 'Findings and Recommendations with Regard to Compliance by Ukraine with the Obligations under the Aarhus Convention in the Case of Bystre Deep-water Navigation Canal Construction (Submission ACCC/S/2004/01 by Romania and Communication ACCC/C/2004/03 by Ecopravo-Lviv (Ukraine))' UN Doc ECE/MP.PP/C.1/2005/2/Add.3 (14 March 2005) para 34; and ACCC 'Compliance by the European Community with Its Obligations under the Convention' UN Doc ECE/MP.PP/2008/5/Add.10 (2 May 2008) para 58.

${ }^{196}$ ACCC 'Findings and Recommendations with Regard to Compliance by Kazakhstan with the Obligations under the Aarhus Convention in the Case of Information Requested from Kazatomprom (Communication ACCC/C/2004/01 by Green Salvation (Kazakhstan))' UN Doc ECE/MP.PP/C.1/2005/2/Add.1 (11 March 2005) para 23.

${ }^{197}$ See, e.g., Scottish Government, 'Access to Environmental Information - Guidance for Scottish Public Authorities and Interested Parties' (November 2004) <https://www.gov.scot/Resource/Doc/26800/0014460.pdf>. ${ }^{198}$ Peru had recommended the inclusion of the ILO Convention No. 169 and the UN Declaration on the Rights of Indigenous Peoples.
} 
Commissioner were issued. ${ }^{199}$ In a landmark case, Smartsource v Information Commissioner, the question at issue was whether private water utilities companies could be deemed public authorities in terms of access to environmental information. ${ }^{200}$ The final decision rejected the argument that these water and sewage undertakings in the context of privatization were not public authorities, and would therefore be under no obligation to disclose environmental information. ${ }^{201}$ Notwithstanding the regional differences, this case law could shed light on the functions and interpretation of the legal texts or, at least, anticipate the possible controversial issues.

Guaranteeing public participation in decision making in environmental matters has as a premise the definition of its scope. The ACCC has determined that the environmental character of decision making has to be interpreted in its specific context, 'taking into account the particular needs of a given country and the subject matter of the decision-making'. ${ }^{202}$ Environmental decision making could consist of several different acts taking place at different stages. Therefore, public participation should be respected on all occasions, as the ACCC has established: '[w]ithin each and every such procedure where public participation is required, it should be provided early in the procedure, when all options are open and effective public participation can take place. ${ }^{203}$ Again, States should make explicit what remedies are available in domestic law to protect the right.

As for the access to environmental justice, in some cases in Europe (e.g. Sattelberg) concerning legal standing of NGOs pursuing a claim in a different country, Italian courts clarified that according to the principle of non-discrimination on the grounds of nationality, those NGOs should have legal standing. ${ }^{204}$ Judicial independence in the access to environmental justice should be regarded as a condition in LAC since, as the ACCC noted, 'judicial independence, both individual and institutional, is one of the preconditions in ensuring fairness in the access to justice process' ${ }^{205}$ As points for future consideration, in Europe NGOs have indicated that problems encountered in getting access to justice relate, among others, to standing conditions, scope of the court, review of acts and omissions in environmental matters, and the effectiveness and timeliness of a court review. ${ }^{206}$

On the costs of access to justice, the ACCC has determined that 'in the light of the standard set by article 9, paragraph 4, of the Convention, the Committee considers the cost system as a whole and in a systemic manner'. ${ }^{207}$ In Europe, States have drawn the attention to cross-undertakings in the injunctions, which increase the costs. ${ }^{208}$ These costs are regarded as

\footnotetext{
${ }^{199}$ Environmental Information (Scotland) Regulations 2004.

${ }^{200}$ Smartsource v Information Commissioner [2011] 1 Info LR 1498 (Upper Tribunal).

${ }^{201}$ See also Case C-279/12, Fish Legal and Shirley, ECLI:EU:C:2013:853.

202 ACCC 'Compliance by the Lithuania with Its Obligations under the Convention' UN Doc ECE/MP.PP/2008/5/Add.6 (4 April 2008) para 71.

203 ibid.

${ }^{204}$ Italian Ministry for the Environment and the Sea, 'Sattelberg Wind Plant and Support to Energy Production from Renewable Resources', Fourth Update of the National Report by Italy on the Implementation of the Aarhus Convention (2017) 32.

${ }^{205}$ ACCC 'Findings and Recommendations with Regard to Compliance by Kazakhstan with the Obligations under the Aarhus Convention in the Case of Access to Justice in the court of Medeuski region of Almaty (Communication ACCC/C/2004/06 by Ms. Gatina, Mr. Gatin and Ms. Konyushkova (Kazakhstan)) Kazakhstan' UN Doc ECE/MP.PP/C.1/2006/4/Add.1 (28 July 2006) para 24.

${ }^{206}$ P Černý, 'Practical Application of Article 9 of the Aarhus Convention in Some EU countries - Comparative Remarks' in Environmental Law Service et al, Selected Problems of the Aarhus Convention Application Based on Experience and Court Practice of NGOs in 7 EU countries (April 2009).

207 ACCC 'Findings and Recommendations with Regard to communication ACCC/C/2008/33 Concerning Compliance by the United Kingdom of Great Britain and Northern Ireland' UN Doc ACCC/C/2008/33, ECE/MP.PP/C.1/2010/6/Add.3 (December 2010) para 128 (ACCC - United Kingdom).

${ }^{208}$ Case C-530/11, Commission v United Kingdom, ECLI:EU:C:2014:67.
} 
an obstacle to environmental justice: the ACCC has considered that injunctive relief is not pursued, because of the high costs at risk, where the claimant is legitimately pursuing environmental concerns that involve the public interest [s] uch effects would amount to prohibitively expensive procedures that are not in compliance with article 9, paragraph 4'. ${ }^{209}$ By relying on this practice, the CIC can interpret RAEAR to monitor the effective implementation of its provisions, bearing in mind regional specificities.

\subsection{Designing an effective RAEAR implementation strategy}

To increase the effectiveness of the RAEAR, some crucial aspects to engage LAC States in compliance should be addressed. As discussed earlier, the Aarhus Convention has developed a relatively advanced compliance mechanism with experience accumulated over the years, which may offer valuable guidance for the CIC. For instance, parties to the RAEAR should adopt similar rules for the handling of communications. In checking compliance with the agreement provisions, States concerned should be given the possibility to present their pleadings, as has been established in the ACCC. Rather than pointing at the non-compliers as the culprits of environmental degradation, a more collaborative approach should be taken. Evidently, information about how to gain access to the CIC (containing clear and precise guidelines) should be disseminated amongst the relevant users of the system (citizens and NGOs), and reports on compliance should be made available to the public.

Comparing the RAEAR to the Aarhus Convention, it is possible to observe an evolution in international environmental law and the different generations of rights. ${ }^{210}$ Of the environmental access rights as formulated in the Rio Declaration, in the Aarhus Convention only access to environmental information is formulated in human rights language. In the RAEAR, all rights are imbued with human rights considerations. In comparison, the case law of the ACCC is more concerned with specific aspects of effective implementation relying on international environmental law principles, giving rise to clear implications for domestic environmental legislation.

A successful implementation strategy should also involve cooperation with subregional organizations. ${ }^{211}$ LAC States have adopted subregional strategies and agreements for environmental protection that may be used as a blueprint for the RAEAR. ${ }^{212}$ Under the umbrella of the CCAD, Central American States have signed agreements on biodiversity, climate change, hazardous wastes and forest conservation. Mercosur has launched a Ramsar implementation strategy through its specialized working group on environment and sustainable development. The Andean Community has designed its own regional biodiversity strategy. ${ }^{213}$ Other examples include the common strategy for implementation of the UNFCCC, and the 2002 General guidelines for the implementation of environmental law at the national level

\footnotetext{
${ }^{209}$ ACCC - United Kingdom (n 207) para 133.

${ }^{210}$ M Fitzmaurice, 'Environmental Degradation' in D Moeckli and S Sivakumaran (eds), International Human Rights Law (2nd edn, Oxford University Press 2014) 590.

${ }^{211}$ The CoP has an express mandate to develop cooperation pursuant to RAEAR (n 55) art 12(5)(b).

${ }^{212}$ GL Rose, 'Gaps in the Implementation of Environmental Law at the National, Regional and Global Level', First Preparatory Meeting of the World Congress on Justice, Governance and Law for Environmental Sustainability, Kuala Lumpur, Malaysia (12-13 October 2011).

213 Ramsar Convention, 'Overview of the Implemantation of the Convention in the Neotropical Region' (2 September 2005) <http://archive.ramsar.org/cda/fr/ramsar-documents-cops-cop6-6th-meeting-of-the19469/main/ramsar/1-31-58-129\%5E19469_4000_1> para 99; Andean Community, 'Estrategia Regional de Biodiversidad para los - Países del Trópico Andino' $<$ http://www.comunidadandina.org/StaticFiles/201166155342libroERB_final.pdf>.
} 
adopted by Caribbean countries. ${ }^{214}$ Similarly, regional strategies could be deployed to encourage effective compliance with the RAEAR.

However, there are some limitations to this approach. The RAEAR is intended to be restricted to signature and ratification by LAC countries. ${ }^{215}$ No provision explicitly foresees the possibility of it being ratified by international organizations, despite the many organizations already operating in LAC. Without a proper endorsement of the RAEAR non-compliance procedure, there would be little incentive for organizations to submit complaints, creating a potential disincentive for compliance.

Perhaps an effective implementation strategy for the RAEAR would be to find common ground between international human rights law and environmental law. In certain regards the RAEAR marks an evolution from Aarhus, as the text contains new approaches to access rights. However, whether the RAER truly is evolving from the Aarhus Convention depends on its implementation and the progressive interpretation of the treaty by the CIC and domestic and regional courts.

In sum, the RAEAR reflects the evolution of international environmental law, manifests the development in terms of access rights, and includes the increasing role of non-stateactors. ${ }^{216}$

\section{CONCLUSIONS}

Although it is too early to draw any firm conclusions, some initial reflections on the RAEAR are possible. Noting the widespread State support for the negotiations and the interest of NGOs in the process, the likelihood of entry into force in the foreseeable future is quite high. Various reasons have prevented the translation of international environmental law into effective domestic norms in LAC. Therefore, the wide implementation of environmental access rights is required.

In view of current environmental threats to the region's natural resources, coupled, at times, with poor environmental governance and compliance with international environmental law, the role that the RAEAR could play, once in force and widely ratified, may be critical. Clearly, the RAEAR is not a panacea for the deficit in the implementation of environmental legislation observed in LAC, but it could make a significant contribution to enhancing compliance and fostering best practices in the field.

While a closer look at the RAEAR's drafting and negotiation process sheds light on its future, the subsequent practice of States will determine whether the RAEAR will be fully implemented. By combining elements of international human rights law, environmental law principles and regional environmental law, the RAEAR represents a step forward in the advancement of environmental access rights. The main implication for the evolution of international environmental law probably lies in that the agreement signifies a move towards consensus towards universal standards for the respect of environmental access rights.

The analysis shows that the work of the UNECE could offer fertile ground for reflection. The success of the Aarhus Convention lies in the fact that its provisions were included almost verbatim by the parties in domestic legislation. Despite the similarities and resemblances, however, the RAEAR is not a mere transplant of European standards and provisions. Whilst the agreement looks quite good on paper, it remains to be seen whether it will be fully implemented. Notwithstanding the challenges ahead, the RAEAR is a step in the

214 INECE, 'Performance Measurement Guidance for Compliance and Enforcement Practitioners' $<\mathrm{http}: / / \mathrm{www}$.inece.org/indicators/guidance.pdf $>$.

${ }^{215}$ RAEAR (n 55) art 20(1)-(2).

216 ibid art 21. Pursuant to Article 22, the Agreement does not admit any reservations. Withdrawal is possible during the first three years, with a year of waiting. 
right direction and a major legal achievement for environmental protection in LAC.

Dr Belén Olmos Giupponi is an Associate Professor of Law at Kingston University London. She holds a PhD in International Law from the University Carlos III of Madrid (2004, summa cum laude); she holds an LLM in Human Rights (University Carlos III) and an MA in International Relations. Dr Olmos Giupponi has undertaken research in EU law, general international law, international economic law, human rights law and environmental law. She has published more than 15 articles in leading journals, including the Leiden Journal of International Law, Transnational Environmental Law, ICSID Review, European Union Journal, Journal of Business Law, Arbitration International, European Energy and Environmental Law Review, Journal of European Legal Studies and the Spanish Yearbook of International Law.

I am grateful to Carlos De Miguel (coordinator of the Principle 10 process) and Georgina Núñez from ECLAC/CEPAL for their kind support and the invitation to take part in the discussions leading to the conclusion of the Escazú Agreement. I would also like to thank the anonymous reviewers and the Editor for their valuable comments. All errors remain mine. 